\title{
O grzeczności w dedykacjach czasów stanisławowskich
}

Wojciech Kaliszewski 


\section{Wojciech Kaliszewski}

\section{O grzeczności w dedykacjach czasów stanisławowskich}

$\mathrm{H}$ istoria recepcji wstępów, adresów i dedykacji, tak bardzo wyrazistych w piśmiennictwie Pierwszej Rzeczypospolitej, powimna być bez wątpienia poszerzona o refleksję nad ich kurtuazyjnym i grzecznościowym charakterem. Taka perspektywa pozostaje dotychczas wlaściwie nierozpoznana. Nic oznacza to oczywiście calkowitego pomijania czy ignorowania przez badaczy problematyki związków tekstu dedykacyjnego z następującym po nim utworem. Dedykacja jako wypowiedź zrośnięta z dziclem ramą pisarskiej koncepcji dostarczać może, i dostarcza, licznych implikacji, związanych na przyklad z zagadnieniami odbioru i odbiorcy w procesie historycznoliterackim. Są to kwestie, których tutaj rozwijać nadmiernie, jak sądzę, nie trzeba'. Czym innym jednak jest próba opisu roli i znaczenia odbiorcy dziela literackiego w gatunkach stricte literackich, a czym innym zwrócenie uwagi na postać tak wyjątkowa jak wybrany i wskazany przez autora konkretny adresat dedykacji. W tym wypadku badacz staje na granicy łączącej świat fikcyjny ze światem osób realnych, w polı widzenia pojawiajz się więc postacie zewnętrzne i wewnętrzne, wchodzące ze sobą w liczne relacje. Przedmiotem refleksji staje się tym samym związek praktyki pisarskiej z akceptowanym w danym czasie systemem odniesień międzyludzkich, wśród których grzeczność odgrywala niepoślednią rolę.

Zwyczaj dedykowania utworów osobom z jakichś szczególnych powodów zasłużonym i znaczącym dla autora był w XVIII wieku ciągle jeszcze cząstką żywej tradycji, która określała i podtrzymywała bezpośrednie stosunki pomiędzy użytkownikami kultury. Formuły, wyrażenia i zwroty dedykacyjne miały swoje korzenic w mowie o charakterze uroczystym, i przy-

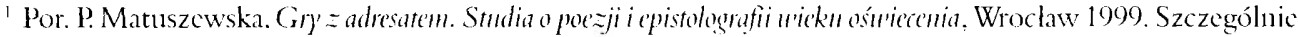
interesujące dla wspomniancj tematyki są tutaj rozdzialy: Z problemat) ki redacji osolon'yde u' poczji stanistan'ou'-

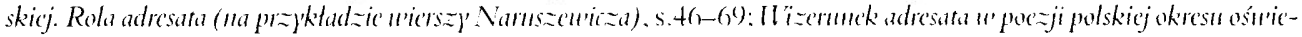
chlia, s. 8t-93.
} 
pominały o retorycznym czynniku spajającym przez długie dziesięciolecia szlachecką wspólnotę stanową. Stabilizowały także trwałość zwyczajów związanych z lekturą. Konwencjonalizacja zwrotów i wyrażeń pierwotnie związanych z autentycznymi uczuciami mówiącego, wtórnie, poprzez obowiązek użycia, służyła wlaściwemu kształtowaniu i uzewnętrznianiu emocji. Zasady konstruowania grzecznej dedykacji wpajano skutecznie pokoleniom studentów kolegiów.

Teksty dedykacyjne nie zaskakiwaly na przestrzeni stuleci swych odbiorców nagłymi zwrotami, skokami i zmianami formalnymi, przeciwnie - z punktu widzenia czytelnika przyjęte i wypracowane wcześniej sposoby recepcji nie musiały się zmieniać, były wciąż funkcjonalne.

Dedykacyjne wyróżnienie konkretnego odbiorcy lub całej grupy adresatów, zgodnie z zasadami grzeczności, odpowiadało przyjętym w świecie szlacheckim wartościom i zachowaniom, wśród których obyczaj ofiarowania komuś rzeczy godnej byl rozpowszechniony. Leksyka i rodzaj zastosowanych przez autora środków stylistycznych wyrażały za każdym razem stopień hierarchicznej zależności pomiędzy nadawcą i odbiorcą, i gwarantowały także samemu mówiącemu należyty szacunek. Dopiero kres istnienia Rzeczypospolitej stał się ostatecznie kresem tej tradycji, a także pisarskiej potrzeby stanowiącej fundament tekstu dedykacyjnego. Późniejsze dedykacje literackie to daleko posunięte mutacje adresów rozsianych po kartach wstępnych piśmiennictwa przedrozbiorowego, nastawione na przełamywanie retorycznej dostojności. Ale już w drugiej polowie XVIII wieku wyraźnie zarysowuje się bardziej osobisty i przez to mniej konwencjonalny sposób zwracania się autora do czytelnika.

W moich uwagach chcę przedstawić trzy typy dedykacji odpowiadające gatunkowo i funkcjonalnie zróżnicowanym kręgom piśmiennictwa oświeceniowego. Typ pierwszy nazywam dedykacją k róle w sko-d w o r s k ą. Jej patetyczny i ściśle konwencjonalny charakter odpowiadal zazwyczaj odzie. Typ drugi traktuję jako dedykację z i e m i a ń s k o-w s pól no tow ą - i tutaj badacz możne siçgnąć, szukając porównań, do szeroko stosowanego wówczas repertuaru gatunków lirycznych, w których dominantę stanowil zwrot do drugiej osoby Typ trzeciokreślam jako dedykację o charakterze a pe la t y w no-pers wa z y j y m. Pojawiala się ona w bardzo wielu utworach skierowanych na sprawy publiczne i polityczne. Autor, świadom perswazyjnego znaczenia tekstu, korzystal szeroko w tego typu dedykacjach z pomocy retoryki. Taki podzial pozwala dostrzec istotne cechy motywacyjne, kompozycyjne i stylistyczne wyrażające ostatecznie poprzez piśmiennictwo miejsce człowieka w spoleczeństwie, wpisując się ponadto w porządek podstawowych sytuacji komunikacyjnych czasów stanisławowskich.

Dedykacja pierwszego typu lączy siç z rozumieniem piśmiennictwa ,jako medium elitarno-towarzyskich, wewnątrzgrupowych kontaktów", ale sytuuje się jednocześnie w obrębie ,.działalności polityczno-agitacyjuej”. Wyróżniony drugi typ odpowiada „sytuacji utylitarno-zabawowego użytkowania piśmiennic twa”, ale także „obcowania z piśmiennictwem jakc samodzielną wartością kulturową". I w końcu trzeci typ wiąże się z , sytuacją użytkowania piśmiennictwa jako dzialalności polityczno-agitacyjnej” i zarazem uczestniczy w „sytuacji pro- 
gramowo-edukacyjnego użytkowania piśniennictwa"? Wpisanie dedykacji w system różnorodnych sytuacji komunikacyjnych pozwala na pewno dokładniej określić charakter relacji łączących użytkowników literatury czasów stanisławowskich. Jednocześnie należy pamiętać, że przyjęcie powyższych zróżnicowań dotyczy bardzo wielu poziomów i obiegów kommikacyjnych.

Adresat dedykacji, poprzez przywolanie, stawał siç odbiorcą określonej racji, spełniając, w założeniu autora, warunki osoby otwartej na przekazywane w ten sposób przesłanie. Tekst dedykacji byl dla piszącego tekstem pozwalającym sygnalizować treści ważne dla jakiegoś kręgu czytelników, ale za sprawą obecności konkretnego adresata - swoistego reprezentanta zbiorowości - autor mógł posługiwać się kurtuazyjnym dystansem. Grzeczność pomagała krytykować przeciwnika, tonowała emocje i sprzyjała porządkowaniu argumentów. Pozwalalo to na przekazywanie z jednej strony treści czysto informacyjnych, a z drugiej strony grzeczne zwroty skłanialy odbiorców do okazania autorowi sympatii. W ten sposób stwarzano lepsze warunki dla przekonywania przeciwnika do swoich racji. 1)edykacyjna grzeczność zakreślała poza tym granice świata uporządkowanego, w którym hierarchia była dla jego mieszkańców czymś oczywistym. Czytelnik był zazwyczaj świadom tych wszystkich zabiegów, które nie odnosiły się jednak tylko do literatury i nie miały tylko wymiaru listorycznego, ale takze obowiązywały na co dzień w świecie realnym.

I Iistoryk literatury, badając teksty osiemnastowiecznych dedykacji, napotyka splot tych i wielı innych relacji, zarówno wewnątrztekstowych, jak i odsylających wprost poza granice utworu. Nie może więc zignnorować faktu, iż dedykacja, wyrastająca ze wspomnianej wcześniej tradycji polityczno-retorycznej, mieścila się również w sposób znaczący w wyższej, czy nadrzędnej wobec wielu dziedzin ówczesnego życia, sferze grzeczności. Grzeczność kierowała bowiem zachowaniem człowieka wobec czlowieka poprzez szereg cnót utrwalanych przede wszystkim za sprawą rzeczywistych autorytetów, a w dalszej kolejności dopiero za pośrednictwem skodyfikowanych zasid. U jej podstaw leżała potrzeba dzialania i mówienia rozsądnego, służącego dobrze każdej słusznej sprawie. W sposób jasny ujjmowal tę różnicę w 1771 roku na łamach „Zabaw Przyjemnych i Pożytecznych” jezuita Franciszek Bieńkowski, wicerektor jezuickiego Collegium Nobilium. Ten zasłuzony pedagog pisal:

Niech kto będzie usłużnym, uczynnym i względnym, kiedy jednak tego samego nie czyni grzecznie, może być poczytany za człowieka nczciwego i dobrego, ale nie za grzecznego. Grzeczność i obyczajność nie jest toż samo. Być grzecznym jest coś więcej niz być obyczajnym. Kto ma grzeczność, musi koniecznie mieć i obyczajność, ale obyczajność może być bez grzeczności. Obyczajność uważa, co mówić i czynić należy, a grzeczność i na to wzgląd mieć powinna, żeby toż samo przyjemnym i roztropnym sposobem mówiono lub czyniono. Obyczajnym może być czlowick i prostego gminu, ale grzecznym będzie, chy- 
ba ten, który z godnymi i grzecznymi przestawał. Rzymianie nazywali grzeczność urbanitas albo elegantia mormm ${ }^{3}$.

Grzeczność była więc niewątpliwie w swej ulotności bliska kwestii smaku. Była kategorią wyróżniającą nic tylko sposób bycia i zachowania w kontaktach bezpośrednich, ale także kategorią określającą ton wypowiedzi dedykacyjnej. Grzeczność byla wartością samą w sobie, na pewno pojawiała się przed sferą obyczajów jako coś, co łączyło wybranych ludzi w sposób szczególny Stojąca w centrum dedykacji osoba adresata stawała się z obiektem grzecznościowych zabiegów autora, czyniąc z tak zwanej „wewnątrztekstowej komunikacji” problem bardziej złożony. W przypadku dedykacji, inaczej niż w systemie tradycyjnych gatunków literackich, odbiorca pojawiał się przed czytelnikiem niby aktor na dobrze oświetlonej scenie. Był odkryty, często tożsamy z postacią istniejącą naprawdę. O ile więc odbiorca wirtualny rzeczywiście naruszal spójność dzieła jako uporządkowanej całości, o tyle tak ukonkretniona postać obecna w dedykacji szła jeszcze dalej — odsyłała czytelnika bez żadnego kamuflażu na zewnątrz, poza granice utworu. Tutaj chodziło o poruszenie w pełni żywego odbiorcy, zdolnego czerpać z potencjahu „energii grzeczności” zgromadzonej przez autora w samym tekściet.

Grzeczność była czymś niezmiennym, niezależnym od samego utworu dedykacyjnego, czymś wobec niego pierwotnym, ale i przerastającym go, i znacznie dalej wychylonym w czasie. Dedykacja wyrastała z określonej sytuacji, którą przeżywał i w której uczestniczył autor, ale wchodziła zarazem w przyszly bieg życia odbiorcy, nabierając nieustannie nowych znaczeń wzorcotwórczych, podtrzymujących istnienie świata wartości przyjętych za najwyższe i najważniejsze z punktu widzenia trwałości spoleczeństwa. Naruszenie zasad grzeczności było wyzwaniem stawianym światı. Ten, kto decydował się na taki krok, musiał zdawać sobie sprawę z konsekwencji. Jedną z nich mogło być i nierzadko bywało rozstrzygnięcie na placu pojedynkowym.

Dedykacje typu królewsko-dworskiego stanowiły rozpoznawalną funkcję stalych relacji osobowych charakteryzujących dosyć specyficzną grupę wybraną spośród ogólu spolecznego. Stworzona w ten sposób sytuacja komunikacyjna służyła przenoszeniu przez reprezentantów środowiska treści i poglądów słuzących budowaniu zdecydowanie pozytywnego wizerunku adresata. Dedykacja skierowana do umiłowanego władcy zbliżała się do roli utworu panegirycznego, opartego na kompletowaniu listy zasług i przymiotów godnych najwyzszej czci.

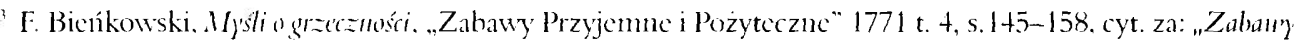
Przyjemne i Poiftec (BN I 195)]. S. 1(19)-110.

+ Odwohję siç tutaj do uwag Janusza Slawińskiego na temat ..wewnątrztekstowej sytuacji komunikacyjnej”

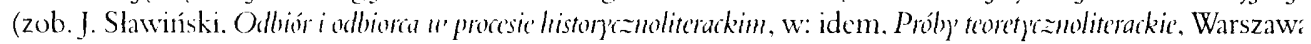
1992. s. 7+91). Model strukturalny tekstu ma dla mnic znaczenie przede wszystkin pomocnicze i shizy opi. sowi dzicha. ktore uczestniczy w rzeczywistym ubiegu kommikacyjnym. 
Przykladem tej odmiany dedykacji niech będzie tekst poprzedzający laciniską Odę o mądr'mm królu z roku 1764, autorstwa Stanisława Konarskiego ${ }^{5}$. Spetniająca wymagania dydaktycznego uniwersalizmu Oda obrastala pod wplywem rzeczywistych wypadków w coraz to nowe komentarze. W tej aktualizacji utworu brał udział sam autor. Jak mówił (podaję za thumaczeniem Marcina Eysymonta):

W samych prawic początkach bezkrólewia, gdy o ozdobie narodı Stanisławie Poniatowskim, do królestwa kandydacie, pierwsze były między nami rozmowy, oda ta o mądrym królu przyjaciołom prześpiewana była.

Wizerunek mądrego i dobrego władcy nakréslony w Odzie - czytany dalej — miał rzekomo pasować - zdaniem wszystkich - idealnie do kandydata Familii, Stanisława Poniatowskiego. I skoro „glos jeden był wszystkich powszechny”, znaczyć to mialow intencji pisarza, że ostatecznie oda doskonale spełnila swą agitacyjno-agitacyjno-polityczną misję. W końcu to właśnie Poniatowski został królem i wcielił się w tę postać doskonałego władcy. Autokomentarz Konarskiego wzmacuiał pochwalną wymowę całego utworu, i — co najważniejsze - wskazywał na autora jako na przenikliwego architekta polskiej rzeczywistości politycznej.

Po elekcji Konarshi pospieszył z dedykacją nowoobranemu monarsze, poszerzając o nią krążącą od kilku miesięcy w kręgach pijarskich Odę. Dedykacja jest patetyczną przemową, uzasadniająca postawienie przy imieniu króla dwóch ıtrzymanych w stopniu najwyższym przymiotników: „najjaśniejszemu i najpotężnicjszemu”. Takie jest zadanie pięćdziesięciu kolejnych wersów dedykacji. Konarski postępuje w zgodzie z poetyką wiersza panegirycznego, chwaląc pochodzenie króla, jego talenty, wdzięk i zdolności, zapewniając władcę o wielkiej milości i wdzięczności calego narodu. Poszczególne sekwencje dedykacji skladają się na wizerunek doskonalego władcy, potwierdzają trafność decyzji elektorów i wskazują na Poniatowskiego jako na męża opatrznościowego, którego los zesłał Polsce. Pominimy jednak cała panegiryczną, spetryfikowaną wymowę dedykacji Konarskiego, i spróbujmy spod tej warstwy wydobyć to, co wiąże się z grzecznością muiej oficjalną. Uwagę czytelnika zwróci niewątpliwie wyraźnie zaznaczona, także poprzez różnice objętościowe, dysproporcja w sposobie prezentacji adresata i nadawcy. Autor poświęca królowi kolejne wersy, które stają się znaczącymi składnikami coraz pełniejszego i wręcz głębszego obrazu poetyckiego monarchy. Pierwszy wers wprost wskazujący na adresata - „Stanisławowi Augustowi” — otwiera klamrę spinająca pochwalny portret władcy. Człon zanykający układ brzmi: „królowi mądremu”. Konarski prowadzi czytelnika od adresu imiennego do formuly wyrażającej najwyższą z możliwych ocen postaci władcy. W ten sposób wszystkie inne wypowiedziane tutaj treści i wymienione cechy nowoobranego wladcy zostają podporządkowane wartości prymarnej i dla autora nadrzędnej - mądrości. Wokól tego motywu zostaje zbudowana cała wypowiedź, tutaj zbiegaja

\footnotetext{
${ }^{5}$ Wszystkic cytaty z Ody za: S. Konarski, Operalyrica. [Warszawa, Druk. Pijarów:] 1767, s. 85-99 (th. M Eysymonta).
} 
się wszystkie jej wątki. I wobec tak przedstawionego adresata postać nadawcy i zarazem ofiarodawcy wiersza wydaje się rzeczywiście rysować nader skromnie:

\author{
(...) w krótkich słowach \\ królowi mądremu \\ wiersz liryczny obowiązki króla \\ zawierający \\ Stanistaw Konarski szkól pobożnych \\ na daninę \\ winnego od siebie i calego zgromadzenia \\ majestatowi uszanowania \\ ofiaruje
}

Ale proste i zwięzle „ofiarowanie“ Od $\gamma^{\prime}$ pozbawione wiernopoddańczej przesadni, nie tylko nie narusza poczucia harmonii calości, lecz przeciwnie - tę harmonię, poprzez zachowanie właściwych proporcji i stosumek części do calości, czyni bardziej odczuwalną. Przede wszystkim dlatego, że autor chce ofiarować królowi dar o wielkim ciężarze jakościowym wzorzec spójnego systemu wartości moralnych. Ponadto nadawca staje w kręgu współbraci zakonnych, i tym sannym jego słowa zdają się brzmieć rzeczywiście dobitnie, to są słowa wypowiadane zbiorowo i z myśli podzielanych przez wspólnotę wyrastają. Dzięki nim utrzymana zostaje jakby „ilościowa” równowaga pomiędzy skromnym mówcą a majestatycznym adresatem. Konarski chwali króla nie tylko dlatego, że tak każe mu obyczaj, ale czyni to, jeśli nie z prawdziwej potrzeby serca, to na pewno z podpowiedzi rozumu. W Poniatowskim naprawdę widzi godnego czci wladcę, któremu należy pomóc, zaopatrując go w swoisty katalog cech dobrego króla. Nie czyni tego gwaltownie, nie narzuca adresatowi swojej osoby. Postępuje grzecznie, i chwaląc - doradza i podpowiada. Takt i umiar są w dedykacji Konarskiego nie tyle wędzidłem, ile znakiem prawdziwej i głęboko rozumianej mądrej grzeczności, wykluczającej zarazem jakąkolwiek czołobitność autora.

Do króla należało zwracać siç w sposób przepisany zasadami grzeczności. Oda Konarskiego w pehni respektuje nie tylko tę zasadę, ale i reguły stylu podniosłego, budzącego zachętę do podejmowania wielkich czynów. Autor przypomina, że adresat jest spokrewniony przez matkę z potężnymi Jagiellonami, a to w polączeniu z:

\footnotetext{
...lagodnością, roztropnością,

radą, męstwem, wspaniałością

urody i stodką wymową...
}

czyni go jedynym godnym spadkobiercą korony polskiej. Po takim kandydacie można spodziewać się dzialań, które przywrócą Rzeczypospolitej blask dawnej potęgi. 
Konarski zręcznie posłuży się w przypadkı swojej dedykacji retorycznym rodzajem demonstratywnym, ale ton panegiryczny, w przypadku tak znakomitego pisarza, jakim byl rzeczywiście autor Ody', nie wynikal tylko z prostego przeciwicústwa spolecznych pozycji króla i poddanego. Konarski rzeczywiście zwracał się z nadzieją do czlowieka o określonych cechach umystu i charakteru. W tej sytuacji szczera akceptacja kogoś drugiego implikowała niewymuszoną grzeczność, bo - jak pisał wspomniany jezuita Bieńkowski —

Trudno z tymi grzeczności obowiązki zachować, którzy się nam nie podobają. Ludzie oświeceni w tym są nieszczęśliwi, iż malo takich znajdıją, którzy im do serca przypaść moga. Im więcej kto ma oświecenia, tym łatwiej w drugim przywarę postrzeże. (...) Kto mię chwali dowcipuą i wyborną myślą, zdaje się, iż bardziej to czyni dla pokazania swego dowcipu niz dla mojej osoby szacunku".

Autor $O d y^{\prime}$ o madry'm królı, stając w cienuiu swego adresata, nie przestawal być mimo to widziany i dostrzegany. Paradoksalnie można powiedzié, że oświetlony zostal owym cieniem i to, co mówił zyskiwało status prawdy. Tak pozaliteracka relacja grzecznościowa przekładała się na etyczıą wartość tekstu dedykacji.

W kręgu dedykacji ziemiańsko-wspólnotowych relacje pomiędzy wewnątrztekstowym nadawcą i adresatem ksztaltują się na zasadach daleko bardzicj osobistych, bliższych niż w oficjalnych dedykacjach dworskich. Niejednokrotnie autor wskazuje na taki rodzaj osobowych stosunków poprzez sam tytul utworu dedykacyjnego. Wymienia on zazwyczaj w tytułowej formule adresata z imienia i nazwiska, przybliża go, często także precyzyjnie charakteryzuje jego miejsce w hierarchii społecznej i do niego wprost kieruje treść utworu następującego po dedykacji. Zidentyfikowana w ten sposób postać odsylala czytelnika do tak zwanego adresata zewnętrznego, wskazıjąc na kontekst personalny dedykacji. Ten niezwykle ciekawy i często intrygujący dla badacza trop prowadzi między innymi na teren reakcji i potrzeb psychologicznych. Poszukiwanie więzi z drugim człowiekiem, chẹć obdarowania osoby z jakichś względów wybranej i godnej zaufania - to niewątpliwie istotne czynniki inspirujące do sformulowania i publicznego przedstawienia dedykacji. Dedykacja jest także rodzajem dzialania jednającego i zbliżającego lıdzi do sicbie. Unicjętne pozyskanie czyjejś przychylności wiązalo się wprost z nauką o grzeczności. Ignacy Krasicki w Uu'agach radzil i zalecat:

Każdy człowiek przykładać się ile możności powinien do tego, izby drugim stał się przyjemmym i miłym. Działania pierwsze w tej micrze trzymają miejsce, mówienie następne mieć powinno. Samotność nie jest w naturze czlowieka; gdy więc zostawa w towarzystwie, przymilać siç towarzyszom powinien, ażeby nie tylko znośnym się stal, ale wdzięcznym i uprzejmym. Co żcby zdzialal, trzeba, izby przymiotów swoich ku takowemu zamiarowi roztropuie, to jest

\footnotetext{
"F. Bicńkowski, M)'sli..., op. cit., s. 110-111.
} 
skromnic używał; zdrożności zaś swoich, jeżeli zupełnie wykorzenić nie może, przynajmuniej ile możności nic objawial ${ }^{7}$.

Grzeczność i grzeczne zachowanie wedhug autora lana Podstolego stanowi skutek pracy czlowieka nad sobą. W nieustannych jakby zapasach z pychą i dumą zdobywamy cnotę skromności, i im więcej jej w sobie mamy, tym bardziej możemy otwierać się na drugiego człowieka., zbliżać się do niego, rozumiéc go i samemu być rozumianym. Dzięki temu powstaje krąg lıdzi obdarzających się zaufaniem, bliskich sobie poziomem emocji oraz intelektı. W oświeceniu stanisławowskim taka wspólnota poetycko-intelektualna nadawała znacząco ton życiu literackiemu. Ten układ relacji osobowych i towarzyskich otoczenia samego króla odczytać można wlaśnie choćby z tekstów dedykacyjnych.

W roku 1773 na lamach „Zabaw Przyjemnych i Pożytecznych” ukazała się satyra Adama Naruszewicza Sikret, poprzedzona wierszem dedykacyjnym Do Jacka Ogrodzkiego sekretarza w'ielkiego koronnego. Szacunck, jakim Naruszewicz otaczal Ogrodzkiego, potwierdza — warto odnotować - inny wiersz: Na pogrzebie Jacka Ogrodzkiego sekretara wielkiego koronnego, stanowiący prawdziwy portret pochwalny zmarłego. Byla to postać odgrywająca rzeczywiście dużą rolę w otoczenin króla Poniatowskiego, człowiek światły, erudyta; mógł pasować, i pasowal doskonale, do roli mentora. Ogrodzki zostaje w dedykacji potraktowany przez Naruszewicza jako powiernik godny najwyższego zaufania:

Komuż mam lepiej ten rym przypisać, jak tobie,

Cow swej piçkne zebrawszy przymioty osobie

Sekretarza korony, poznaleś nie wezora,

Że gabinet być winicn szkolą Pitagora,

Że przybytki rządzących światem nie są innej

Od pszczelników natury (...)

Adresat jest wybrany ze względı na swoje horyzonty amysłowe, które z kolei są fundamentem postawy moralnej. Dysponıje zatem przymiotami, pozwalającymi widzieć w nim ideał nie tylko męża stanu, ale i troskliwego opiekuna powierzonych jego pieczy osób. Wizja rządów odıiesiona do Pitagorasa akcentıje bezsprzecznie zasadę harmonii, wynikającą z właściwie dobranych i zestawionych proporcji, którą adresat kieruje się na co dzień. Wśród cnót zalecanych przez greckiego mędrca szczególnie istotną wartością czlowieka była gotowość do milczenia. Nadmierne gadulstwo rozkładało i demobilizowało porządek społeczny. Przywołując Pitagorasa, Naruszewicz zbudowal czytelne porównanie; dokonal przy tym konwencjonalnego, zgodnego z rodzajem oceniającym, uwznioślenia adresata dedykacji i scharakteryzowal jego przeciwników łamiących, jak widać, zasady dyskrecji.

Uznanie tych wartości i przywolanie ich charakteryzuje także postawę samego nadawcy — ideały adresata układają się w listę ideałów mówiącego. 1)zieje się tak zarówno na poziomie wewnętrznym, jak i zewnętrzıym tekstu dedykacyjnego. Nadawca staje skrommie — wlaśnie 
tak, jak radzil Krasicki - przed adresatem-mistrzem. Ale uznanie i okazywany szacunck pozwalają zarazem, bez pychy i próżności, wypowied zieć Naruszewiczowi swoje zdanie w kwestii edukacji społeczeństwa:

...Godzi się przy trudzie

Posłuchać, co też Satyr mój na leśnej dudzie

Zanucil na ten motloch, który-ć niennym zowie,

$\dot{Z}_{\mathrm{e}}$ się od ciebie żadnych nowinek nie dowič

Nadawcę i adresata łączy taki sam stosunek do rzeczywistości, taka sama ocena sytuacji i poziomu oświecenia „motłochu” żądnego tanich sensacji, opornego wobec nauki i prawdy, szkalującego światłych obywateli. Naruszewicz zdaje się poprzez wiersz dedykacyjny konstruować jasną koalicję ludzi mądrych, sam ma w niej micjsce i zaprasza sekretarza wielkiego koronnego do wspóludziału w tym gronie.

Trzeci wyróżniony przez muie typ dedykacji miał charakter apelatywno-perswazyjny i służyl przede wszystkim funkcjom pozatekstowym. Taka dedykacja miala trafiać bezpośrednio do wspólnoty czytających i nadawać jej określony kierunck postępowania. Tak uczynił

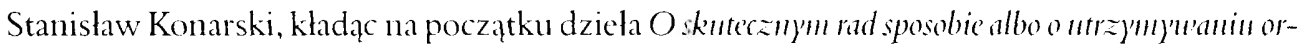

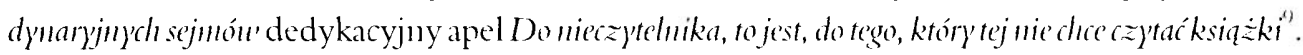
Oto zaskakujące wskazanie na tego, który nie czyta i czytać tekstu nie chce, a jednak jest dla autora kimś bardzo ważnym. We wspólnocie odbiorców ., nieczytelnik” jest przeciwieństwem czytelnika, ale Konarski doskonale wie, że to właśnie ktoś taki, paradoksalnie, pierwszy wystąpi z krytyką. Autor zakładając, że tak się stanie, podejmuıje z odbiorcą grę perswazyjną. Stara się więc przede wszystkim zyskać jego przychylność i odwieść go od wydawania pochopnych sądów:

Azali raczysz te stów kilka przeczytać. O to cię więc, Nieczytelniku, ile mogę, upraszam, abyś ni źlc, ni dobrze o tej książce nie mówil, jeżeli czytać jej nie chcesz, a czytać do konica samego.

Do czytelnika-nieczytelnika zwraca się grzecznie, chce nawiązać z nim bliski, ulatwiający porozumienie, kontakt. Ten ostatni ma służyć przede wszystkim unormowaniu sytuacji odbioru. Autor ma oczywistą koncepcję lektury swojego dzicła - musi ono być odczytane i rozpoznane:

Bo jakże masz sądzić o rzeczy, którejś dobrze i pilnie nie zważyl?

Tak sformulowane pytanic to przykład lagodnego, grzecznego wskazywania „nieczytelnikowi” sposobu dochodzenia do prawdy, stosuje chwyty właściwe dla .perswazji przekonu-

${ }^{\star}$ A. S. Naruszewicz, Do Jacka Ogrodzkiego, sekretara mielkiego korommego, w: idem. Saty'y'. wst. i opr. B. Wolska. Kraków 20112. s. 93-94.

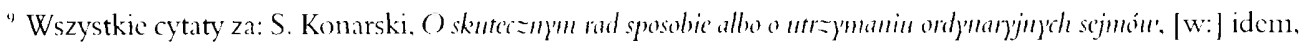
Pisma 1'ybrane, opr. J. Nowak-Dluzewski. wst. Z. Libera. t. 1. Warszawa 1955. s. 105. 
jącej" Mimo wszystko autor nie manifestuje swojej pogardy wobec postawy ignoranta, a przeciwnie, ufa, że ten zrozumie swój błąd. Ten rodzaj perswazji opiera się na powolnym zbliżaniu stanowisk przeciwników. Dlatego tak ważną rolę w wypowiedzi pełnią zwroty osobowe, pozwalające nawiązać z adresatem bliższy i bardziej bezpośredni kontakt. Dopiero potem można próbować nakłonić go do podjęcia trudu lektury dziela przedstawionego, co ostatecznie pozwoli skrzyżować $\mathrm{w}$ dyskusji istotne argumenty:

Jeżeli zaś przemożesz na sobie, abyś ją cierpliwie przeczytał, natenczas feruj na nią dekret, jaki ci się podoba.

Grzeczność okazywana adresatowi ma przede wszystkim doprowadzić do rzeczowej dyskusji, opartej na prawdziwych zasadach.

Konarski w dedykacji Do nieczy'telnika stara się wyzwolić swoje dzieło ze złej tradycji, zadomowionej w społeczności szlacheckiej, polegającej na bagatelizowaniu każdej nowej myśli. Chodzi mu o to, aby utwór był rzeczowo i poważnie, a nie tylko fikcyjnie odbierany.

Zakoníczenie tekstu ma zdecydowanie charakter gestu pojednawczego. Konarski wyciaga rękę do zgody, apeluje do wspólnych wszystkim i najwyższych wartości. Czyni to z pełnym szacunkiem i powaga:

Ufam rozsądkowi i sprawiedliwości twojej, ufam twojej ku Ojczyźnie milości. Niech ci Bóg da zdrowie.

Krasicki w Uu'agach powiadał, że z dwóch ludzi publicznie występujących ten jest człowiekiem naprawdę grzecznym,

który nie siląc się na okazanie nauki, dając drugim sposobność do mówienia, ujął wszystkich i dostąpil bez starania, czego usilność pierwszego wymóc nie mogha.

Ton i sposób zwracania się Konarskiego do nieczytelnika doskonale pasują do słów autora Monachomadiii.

W dedykacji Konarskiego, zbudowanej wedle retorycznych zasad, pojawia się projekt ukladu partnerskiego, równoważącego pozycję autora i odbiorcy. Opiera się on na obopólnym zaufaniu i założeniu, że podstawą powszechnego dobra jest harmonijna więź także pomiędzy ludźmi o różnych poglądach. Umożliwia to pełniejsze poznanie drugiego człowieka, zaakceptowanie jego odmienności i — ostatecznie — twórcze wykorzystanie dramatycznego napięcia rodzącego się pomiędzy dwiema przeciwnościami. Dedykacja stanowiła swoisty, dialogowy punkt startowy całego utworu. W jej tonie, stylı, konstrukcji mieściła się nierzadko zapowiedź wyboru drogi, którą autor chcial podążać do celu.

We wszystkich przytoczonych wyżej typach dedykacji niewątpliwie zauważymy bardzo ważną cechę o charakterze zasady idealizującej relacje międzylıdzkie. Jej źródło bije z samego

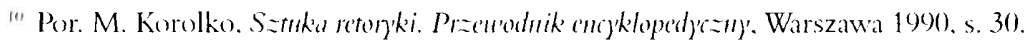


środka grzeczności. Tą cechạjest dążenie do zacierania, pozornych często, różnic i kontrastów pomiędzy postaciami, i akcentowanie tego, co wspólne, i co stanowi cel wspólnego działania nadawcy — zazwyczaj podmiotu wypowiadanych treści - i adresata: dobro Ojczyzny, mądrość, oświecenie, intelektualna otwartość. Tak zarysowana przestrzeń utworu dedykacyjnego sama stawała się z kolei wzorcem grzecznych i wartościowych zachowań. 